\title{
Optimal Synthesis of Refinery Property-Based Water Networks with Electrocoagulation Treatment Systems
}

\section{Supporting Information}

Javier Tovar-Facio, ${ }^{a}$ Luis F. Lira-Barragán, ${ }^{b}$ Fabricio NápolesRivera, ${ }^{a}$ Hisham S. Bamufleh, ${ }^{c}$ José M. Ponce-Ortega, ${ }^{a *}$ and Mahmoud M. El-Halwagi ${ }^{b, c}$

\footnotetext{
${ }^{a}$ Chemical Engineering Department, Universidad Michoacana de San Nicolás de Hidalgo, Morelia, Mich., 58060, México

${ }^{b}$ Chemical Engineering Department, Texas A\&M University, College Station TX, 77843, USA

${ }^{c}$ Department of Chemical and Materials Engineering, Faculty of Engineering, King Abdulaziz University, P. O. Box 80204, Jeddah, 21589, Saudi Arabia
}

\section{Pages: S1-S30}

Tables: Table S1-Table S11 


\section{S1. MATHEMATICAL MODEL}

This sections shows a thorough explanation about proposed mathematical model. A considerable amount of detail was omitted in the manuscript to avoid unnecessary details. The mathematical formulation for this work includes the mass balances and property tracking to model the splitters and mixers considering in the superstructure shown in Figure 2. The formulation also includes the relationships to model the treatment units, the cost functions, and the process an environmental constraint. The following is a detailed description of the model equations.

\section{Mass balances}

The total flowrate inlet to the treatment system $\left(m^{I n}\right)$ is obtained from the different process sources $\left(h_{i}\right)$ as follows:

$m^{I n}=\sum_{i} h_{i}$

This stream enters to all treatment units; however, during the electrocoagulation process there is a water lost. Thus, the stream leaving the electrocoagulation is related to the inlet stream through an efficiency factor $(\beta)$ :

$$
m^{\text {Out }}=m^{\text {In }} \beta
$$

Additionally, the outlet water from the treatment system $\left(m^{\text {Out }}\right)$ is equal to the water sent to the process sinks $\left(g_{j}\right)$ plus the water sent to the reverse osmosis unit $\left(g_{j}^{R O}\right)$ as follows:

$m^{\text {Out }}=\sum_{j} g_{j}+g_{\text {Waste }}+m^{\text {Out }}{ }_{-} R O$

Fresh water $\left(F_{r}\right)$ can be distributed to the different process sinks $\left(f_{r, j}\right)$, except the waste discharge to the environment:

$$
F_{r}=\sum_{j} f_{r, j}, \forall r
$$

The process sources $\left(\mathrm{W}_{\mathrm{i}}\right)$ can be segregated and recycled to the process units $w_{i, j}$, discharged to the environment $\left(w_{i, \text { waste }}\right)$, or sent to the treatment system $\left(h_{i}\right)$ : 
$\mathrm{W}_{\mathrm{i}}=\sum_{j} w_{i, j}+w_{i, \text { Waste }}+h_{i}, \forall i$

The required water for the process units $\left(G_{j}^{\text {Sink }}\right)$ is equal to the fresh water $\left(f_{r, j}\right)$, water directly recycled from the process streams $\left(w_{i, j}\right)$, treated water leaving the electrocoagulation system $\left(g_{j}\right)$ and the treated water processed in the reverse osmosis unit $\left(\mathrm{g}_{j}^{R O}\right)$ :

$\mathrm{G}_{\mathrm{j}}^{\mathrm{Sink}}=\sum_{r} f_{r, j}+\sum_{i} w_{i, j}+g_{j}+\mathrm{g}_{j}^{R O}, \forall j$

The wastewater discharged to the environment (Waste) is equal to the water sent from the process sources $\left(w_{i, j}\right)$, plus the treated water $\left(g_{\text {Waste }}\right)$ and the water from the reverse osmosis unit $\left(\mathrm{g}_{\text {Waste }}^{\text {RO }}\right)$ as follows:

Waste $=\sum_{i} w_{i, \text { Waste }}+g_{\text {Waste }}+\mathrm{g}_{\text {Waste }}^{\text {RO }}$

\section{Property tracking}

The property operator for the stream entering to the treatment unit $\left(\psi_{p}^{\text {InMix }}(P)\right)$ is obtained by the weighted sum of the property operators of the different process sources $\left(\psi_{p, i}^{\text {Source }}(P)\right)$ :

$\psi_{p}^{\text {InMix }}(P) m^{I n}=\sum_{i} \psi_{p, i}^{\text {Source }}(P) h_{i}, \forall p$

It should be noted that the property operators $\left(\psi_{p, i}\right)$ depend on each property and these can be determined experimentally. ${ }^{6}$

The property operator for the sinks $\left(\psi_{p, j}^{S i n k}(P)\right)$ must be equal to the sum of the property operators for fresh sources $\left(\psi_{p, r}^{\text {Fresh }}(P)\right)$, direct recycled sources $\left(\psi_{p, i}^{\text {Source }}(P)\right)$, treated streams $\left(\psi_{p}^{\text {outsplit }}(P)\right)$ and treated water from the reverse osmosis unit $\left(\psi_{p}^{\text {OutSplit }}(P)\right)$ :

$\mathrm{G}_{j} \psi_{p, j}^{\text {Sink }}(P)=\sum_{r} f_{r, j} \psi_{p, r}^{\text {Fresh }}(P)+\sum_{i} w_{i, j} \psi_{p, i}^{\text {Source }}(P)+g_{j} \psi_{p}^{\text {OutSplit }}(P)+g_{j}^{R O} \psi_{p}^{R O}(P), \forall j, j \neq$ waste, $\forall p$

Similarly for the wastewater stream, notice that fresh water cannot be sent to the waste discharge: 
$\mathrm{G}_{\text {waste }} \psi_{p, \text { waste }}^{\text {waste }}(P)=\sum_{i} w_{i, \text { waste }} \psi_{p, i}^{\text {Source }}(P)+g_{\text {wasse }} \psi_{p}^{\text {OutSplit }}(P)+g_{\text {waste }}^{R O} \psi_{p}^{R O}(P), \quad \forall p$

There are specific constraints for the process sinks and for the wastewater discharged to the environment. These constraints are given in terms of lower $\psi_{\mathrm{p}, \mathrm{j}}^{\text {Sink-Min }}(\mathrm{P})$ and upper $\psi_{\mathrm{p}, \mathrm{j}}^{\text {Sink-Max }}(\mathrm{P})$ limits for the property operators for the streams entering the process sinks as follows:

$$
\begin{aligned}
& \psi_{\mathrm{P}, \mathrm{j}}^{\text {Sink_Min }}(\mathrm{P}) \leq \psi_{P, j}^{\text {Sink }}(P) \leq \psi_{\mathrm{P}, \mathrm{j}}^{\text {Sink_Max }}(\mathrm{P}), \forall P, \forall j \\
& \psi_{\mathrm{P}, \text { waste }}^{\text {Sink_Min }}(\mathrm{P}) \leq \psi_{P, \text { waste }}^{\text {Sink }}(P) \leq \psi_{\mathrm{P}, \text { waste }}^{\text {Sink_Max }}(\mathrm{P}), \forall P
\end{aligned}
$$

\section{Treatment units}

First, there is needed to adjust the properties for the inlet stream to desired values, which have been identified through experimental studies.

pH adjustment process

For modelling the treatment system, first it is necessary to consider a $\mathrm{pH}$ adjustment unit to set the $\mathrm{pH}$ of the mixed stream to a desired value. Therefore, if the $\mathrm{pH}$ is greater than the desired one, it is required to add an acid and if the mixed stream has a $\mathrm{pH}$ lower than the desired one, it is necessary to add a base. This is modeled through the following disjunction:

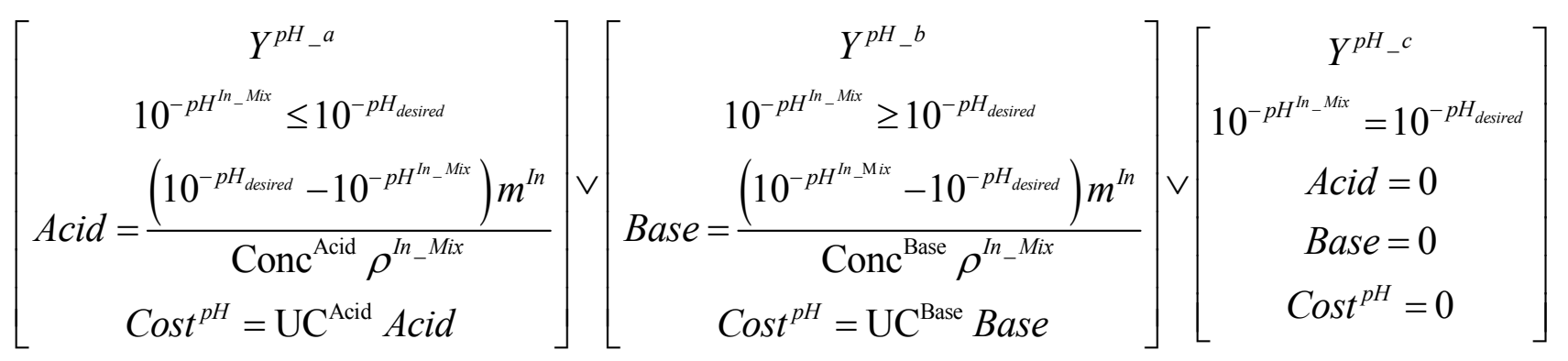

In the previous relationship, the optimization variable is $10^{-p H^{I_{n} M i x}}$, which corresponds to the property operator for the $\mathrm{pH}$. The previous disjunction is reformulated as follows:

First, only one option can be selected, for modelling this, the binary variables $y^{p H_{-} b}$ and $y^{p H_{-} a}$ are introduced for the different segments as follows:

$$
y^{p H_{-} a}+y^{p H_{-} b}+y^{p H_{-} c}=1
$$

Then, if the $\mathrm{pH}$ is greater than the desired value the binary variable $y^{p H_{-} a}$ is activated: 
$10^{-p H^{I n \_\mathrm{Mix}}} \leq 10^{-p H_{\text {desired }}}+\mathrm{M}^{\mathrm{pH}}\left(1-y^{p H_{-} a}\right)$

If the $\mathrm{pH}$ is lower than the desired value, the binary variable $y^{p H_{-} b}$ is activated:

$10^{-p H^{I n_{-} \text {Mix }}} \geq 10^{-p H_{\text {desired }}}-\mathrm{M}^{\mathrm{pH}}\left(1-y^{p H_{-} b}\right)$

When the binary variable $y^{p H_{-} a}$ is activated, then the acid required and the cost for the $\mathrm{pH}$ treatment are calculated through the following relationships:

$$
\begin{aligned}
& \text { Acid } \leq \frac{\left(10^{-p H_{\text {desired }}}-10^{-p H^{I n_{-} M i x}}\right) m^{I n}}{\operatorname{Conc}^{\text {Acid }} \rho^{I_{-} \text {Mix }}}+\mathrm{M}^{\text {Acid }}\left(1-y^{p H_{-} a}\right) \\
& \text { Acid } \geq \frac{\left(10^{-p H_{\text {desired }}}-10^{-p H^{I_{-} M i x}}\right) m^{I n}}{\text { Conc }^{\text {Acid }} \rho^{I n_{-} \text {Mix }}}-\mathrm{M}^{\text {Acid }}\left(1-y^{p H_{-} a}\right) \\
& \operatorname{Cost}^{p H} \geq \mathrm{UC}^{\text {Acid }} \text { Acid }-\mathrm{M}^{\mathrm{Cost}^{\mathrm{pH}}}\left(1-y^{p H_{-} a}\right)
\end{aligned}
$$

On the other hand, if the binary variable $y^{p H \_a}$ is zero, the previous relationships are relaxed through the big-M parameter. Similarly, when the binary variable $y^{p H_{-} b}$ is activated, the corresponding base required is calculated as follows:

$$
\begin{aligned}
& \text { Base } \leq \frac{\left(10^{-p H^{I n_{-} \text {Mix }}}-10^{-p H_{\text {desired }}}\right) m^{I n}}{\text { Conc }^{\text {Base }} \rho^{I n_{-} \text {Mix }}}+\mathrm{M}^{\text {Base }}\left(1-y^{p H_{-} b}\right) \\
& \text { Base } \geq \frac{\left(10^{-p H^{I_{-} \text {Mix }}}-10^{-p H_{\text {desired }}}\right) m^{I n}}{\text { Conc }^{\text {Base }} \rho^{\text {In_Mix }}}-\mathrm{M}^{\text {Base }}\left(1-y^{p H_{-} b}\right)
\end{aligned}
$$

Then, the cost for the $\mathrm{pH}$ is calculated depending on the amount of base used:

$$
\operatorname{Cost}^{p H} \geq \mathrm{UC}^{\text {Base }} \text { Base }-\mathrm{M}^{\mathrm{Cos}^{\mathrm{pH}}}\left(1-y^{p H_{-} b}\right)
$$

When the $\mathrm{pH}$ is equal to the desired value for the electrocoagulation process, the binary variable $y^{p H}{ }_{-} c$ is activated and it is not require to add base or acid to the inlet stream and the cost for $\mathrm{pH}$ treatment will be zero.

$$
10^{-p H^{I n \_M i x}} \leq 10^{-p H_{\text {desired }}}+\mathrm{M}^{\mathrm{pH}}\left(1-y^{p H_{-} c}\right)
$$




$$
\begin{aligned}
& 10^{-p H^{I_{-} M i x}} \geq 10^{-p H_{\text {desired }}}-\mathrm{M}^{\mathrm{pH}}\left(1-y^{p H_{-} c}\right) \\
& \text { Base } \leq \mathrm{M}^{\text {Base }}\left(1-y^{p H_{-} c}\right) \\
& \text { Base } \geq-\mathrm{M}^{\text {Base }}\left(1-y^{p H_{-} c}\right) \\
& \text { Acid } \leq \mathrm{M}^{\text {Acid }}\left(1-y^{p H_{-} c}\right) \\
& \text { Acid } \geq-\mathrm{M}^{\text {Acid }}\left(1-y^{p H_{-} c}\right) \\
& \text { Cost }^{p H} \leq \mathrm{M}^{\text {Cost }^{\mathrm{pH}}}\left(1-y^{p H_{-} c}\right) \\
& \text { Cost }^{p H} \geq-\mathrm{M}^{\text {Cost }^{\mathrm{pH}}}\left(1-y^{p H_{-} c}\right)
\end{aligned}
$$

Otherwise, these equations are also relaxed through the big-M parameter.

\section{Sodium chloride concentration adjustment.}

The concentration of $\mathrm{NaCl}$ is an important property for the electrocoagulation treatment unit. ${ }^{46}$ Thus, if the stream entering to the treatment unit has a concentration lower than the desired value, it is necessary to adjust it through the addition of $\mathrm{NaCl}$. On the other hand, when the $\mathrm{NaCl}$ concentration of the inlet to the treatment stream is greater than the desired value, it is necessary to dilute this stream by adding fresh water to adjust this concentration. This is modeled through the following disjunction:

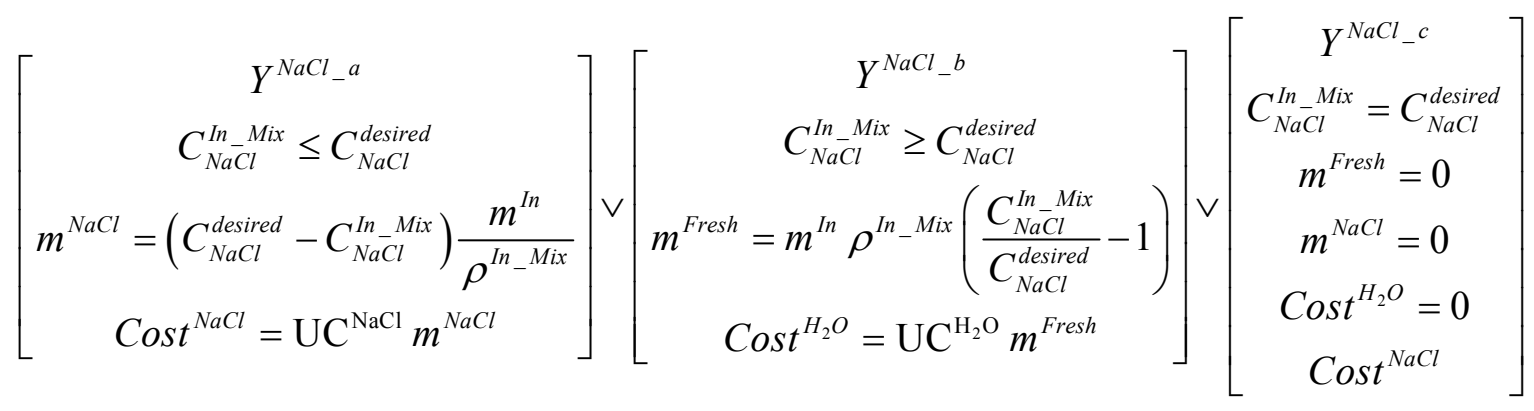

This disjunction is also reformulated in terms of algebraic equations, which include three Boolean variables associated with binary variables. Then, when the stream at the inlet of this unit has a $\mathrm{NaCl}$ concentration lower than the target value, the binary variable $y^{\mathrm{NaCl}_{-} \mathrm{a}}$ is set as one; otherwise $y^{\mathrm{NaCl}_{-} b}$ is equal to one for the case when the concentration is greater than the mentioned value and 
$y^{\mathrm{NaCl}_{-} \mathrm{c}}$ results one when the concentration is equal to the desired value. Then, only one of these options must be selected and this is modeled as follows:

$$
y^{\mathrm{NaCl}_{-} a}+y^{\mathrm{NaCl}_{-} b}+y^{\mathrm{NaCl}_{-} \mathrm{c}}=1
$$

To activate these binary variables, the following relationships are used:

$$
\begin{aligned}
& C^{\mathrm{NaCl}} \leq C_{\mathrm{NaCl}}^{\text {desired }}+\mathrm{M}^{\mathrm{C}^{\mathrm{NaCl}}}\left(1-y^{\mathrm{NaCl}_{-} a}\right) \\
& C^{\mathrm{NaCl}} \geq C_{\mathrm{NaCl}}^{\text {desired }}-\mathrm{M}^{\mathrm{C}^{\mathrm{NaCl}}}\left(1-y^{\mathrm{NaCl}_{-} b}\right) \\
& C^{\mathrm{NaCl}} \leq C_{\mathrm{NaCl}}^{\text {desired }}+\mathrm{M}^{\mathrm{C}^{\mathrm{NaCl}}}\left(1-y^{\mathrm{NaCl}_{-} \mathrm{c}}\right) \\
& C^{\mathrm{NaCl}} \geq C_{\mathrm{NaCl}}^{\text {desired }}-\mathrm{M}^{\mathrm{C}^{\mathrm{NaCl}}}\left(1-y^{\mathrm{NaCl}_{-} \mathrm{c}}\right)
\end{aligned}
$$

When the concentration of $\mathrm{NaCl}$ is lower than the desired value, the binary variable $y^{\mathrm{NaCl}_{-} a}$ is equal to one and the corresponding $\mathrm{NaCl}$ that is required is calculated as follows:

$$
\begin{aligned}
& m^{\mathrm{NaCl}} \leq\left(C_{\mathrm{NaCl}}^{\text {desired }}-C_{\mathrm{NaCl}}^{\mathrm{In}-\mathrm{Mix}}\right) \frac{m^{\mathrm{In}}}{\rho^{\mathrm{In} \_\mathrm{Mix}}}+\mathrm{M}^{\mathrm{NaCl}}\left(1-y^{\mathrm{NaCl}{ }_{-} a}\right) \\
& m^{\mathrm{NaCl}} \geq\left(C_{\mathrm{NaCl}}^{\text {desired }}-C_{\mathrm{NaCl}}^{\mathrm{In}-\mathrm{Mix}}\right) \frac{m^{\mathrm{In}}}{\rho^{\mathrm{In}_{-} \mathrm{Mix}}}-\mathrm{M}^{\mathrm{NaCl}}\left(1-y^{\mathrm{NaCl}{ }_{-} a}\right)
\end{aligned}
$$

If the binary variable $y^{\mathrm{NaCl}_{-} a}$ is equal to zero, no additional $\mathrm{NaCl}$ is required.

Thus, the cost associated with the previous operation is determined as follows:

$$
\begin{aligned}
& \operatorname{Cost}^{\mathrm{NaCl}} \leq \mathrm{UC}^{\mathrm{NaCl}} m^{\mathrm{NaCl}}+\mathrm{M}^{\mathrm{Cost}^{\mathrm{NaCl}}}\left(1-y^{\mathrm{NaCl}_{-} a}\right) \\
& \operatorname{Cost}^{\mathrm{NaCl}} \geq \mathrm{UC}^{\mathrm{NaCl}} m^{\mathrm{NaCl}}-\mathrm{M}^{\mathrm{Cost}^{\mathrm{NaCl}}}\left(1-y^{\mathrm{NaCl}_{-} a}\right)
\end{aligned}
$$

Then, for the case when the $\mathrm{NaCl}$ concentration is greater than the desired value, the binary variable $y^{\mathrm{NaCl}_{-} b}$ is set as one and the corresponding water required to adjust the $\mathrm{NaCl}$ concentration is computed as follows:

$$
m^{\text {Fresh }} \leq m^{\text {In }} \rho^{\text {In_Mix }}\left(\frac{C_{\text {NaCl }}^{\text {In } M i x}}{C_{\text {NaCl }}^{\text {desired }}}-1\right)+\mathrm{M}^{\text {Fresh }}\left(1-y^{\mathrm{NaCl}_{-} b}\right)
$$


$m^{\text {Fresh }} \geq m^{I n} \rho^{I n \_M i x}\left(\frac{C_{N a C l}^{I n-M i x}}{C_{N a C l}^{\text {desired }}}-1\right)-\mathrm{M}^{\mathrm{Fresh}}\left(1-y^{\mathrm{NaCl}{ }_{-} b}\right)$

If the binary variable is zero, no dilution is required.

Through the following relationships, the cost for the case when it is necessary to add fresh water is evaluated:

$$
\begin{aligned}
& \operatorname{Cost}^{\mathrm{H}_{2} \mathrm{O}} \leq \mathrm{UC}^{\mathrm{H}_{2} \mathrm{O}} m^{\text {Fresh }}+\mathrm{M}^{\mathrm{Cost}^{\mathrm{H}_{2} \mathrm{O}}}\left(1-y^{\mathrm{NaCl}_{-} b}\right) \\
& \operatorname{Cost}^{\mathrm{H}_{2} \mathrm{O}} \geq \mathrm{UC}^{\mathrm{H}_{2} \mathrm{O}} m^{\text {Fresh }}-\mathrm{M}^{\mathrm{Cost}^{\mathrm{H}_{2} \mathrm{O}}}\left(1-y^{\mathrm{NaCl}_{-} b}\right)
\end{aligned}
$$

Finally, for the last case when the concentration of $\mathrm{NaCl}$ is equal to the desired value, the binary variable $y^{\mathrm{NaCl}_{-} \mathrm{c}}$ is one. Hence, according to the disjunction, no action is required and the cost is equal to zero for this treatment, which is represented as follows:

$$
\begin{aligned}
& m^{\mathrm{NaCl}} \leq \mathrm{M}^{\mathrm{NaCl}}\left(1-y^{\mathrm{NaCl}{ }_{-}}\right) \\
& m^{\mathrm{NaCl}} \geq-\mathrm{M}^{\mathrm{NaCl}}\left(1-y^{\mathrm{NaCl}_{-} \mathrm{c}}\right) \\
& m^{\text {Fresh }} \leq \mathrm{M}^{\text {Fresh }}\left(1-y^{\mathrm{NaCl}{ }_{-} \mathrm{c}}\right) \\
& m^{\text {Fresh }} \geq-\mathrm{M}^{\text {Fresh }}\left(1-y^{\mathrm{NaCl} l_{-}}\right) \\
& \operatorname{Cost}^{\mathrm{NaCl}} \leq \mathrm{UC}^{\mathrm{NaCl}} m^{\mathrm{NaCl}}+\mathrm{M}^{\mathrm{Cost}}{ }^{\mathrm{NaCl}}\left(1-y^{\mathrm{NaCl}_{-} \mathrm{c}}\right) \\
& \operatorname{Cost}^{\mathrm{NaCl}} \geq \mathrm{UC}^{\mathrm{NaCl}} m^{\mathrm{NaCl}}-\mathrm{M}^{\mathrm{Cost}^{\mathrm{NaCl}}}\left(1-y^{\mathrm{NaCl}{ }_{-}}\right) \\
& \operatorname{Cost}^{\mathrm{H}_{2} \mathrm{O}} \leq \mathrm{UC}^{\mathrm{H}_{2} \mathrm{O}} m^{\text {Fresh }}+\mathrm{M}^{\mathrm{Cost}^{\mathrm{H}_{2} \mathrm{O}}}\left(1-y^{\mathrm{NaCl}_{-} \mathrm{c}}\right) \\
& \operatorname{Cost}^{\mathrm{H}_{2} \mathrm{O}} \geq \mathrm{UC}^{\mathrm{H}_{2} \mathrm{O}} m^{\text {Fresh }}-\mathrm{M}^{\mathrm{Cost}^{\mathrm{H}_{2} \mathrm{O}}}\left(1-y^{\mathrm{NaCl}_{-} \mathrm{c}}\right)
\end{aligned}
$$

\section{Temperature adjustment}

The inlet temperature for the electrocoagulation system has to be adjusted to the desired value. First, if the inlet temperature is greater than this value, then a cooling utility is used to quench it. On the 
other hand, if the inlet temperature is lower than the desired value, steam is employed to raise its temperature. This is modeled through the following disjunction:

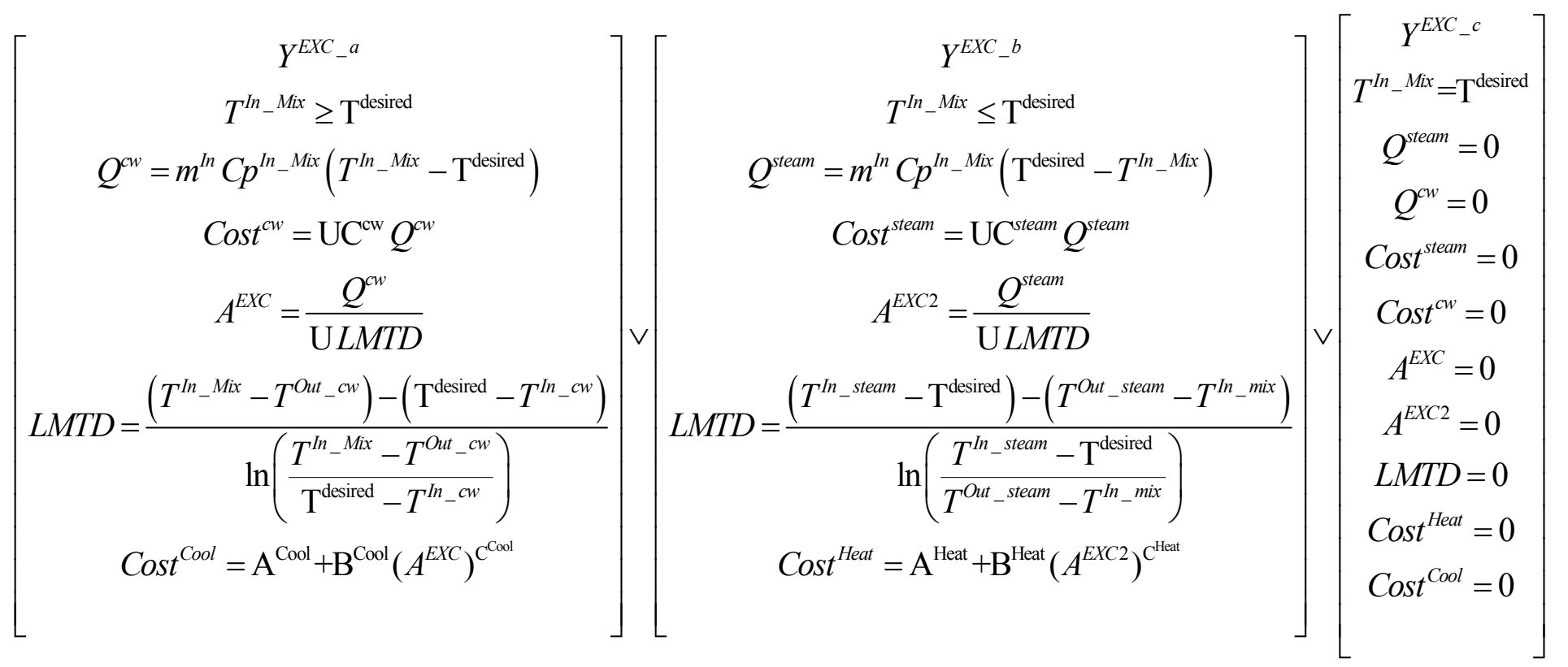

Similar to the previous disjunctions, each Boolean variable is related to a binary variable. The binary variable $y^{E X C_{-} a}$ is employed to model the case when the inlet temperature is greater than $\mathrm{T}^{\text {desired }}$, $y^{E X C_{-} b}$ is used to model the case when the inlet temperature is lower than the desired value, and $y^{E X C_{-} c}$ is used to model the case when the inlet temperature is equal to the optimal value. Then, the following relationship states that only one option can be selected:

$$
y^{E X C_{-} a}+y^{E X C_{-} b}+y^{E X C_{-} c}=1
$$

To activate the binary variable $y^{E X C_{-} a}$, the following relationship is used:

$$
T^{\text {In_Mix }} \geq \mathrm{T}^{\text {desired }}-\mathrm{M}^{\mathrm{T}^{\mathrm{ln}}}\left(1-y^{E X C_{-} a}\right)
$$

To activate the binary variable $y^{E X C_{-} b}$, the following relationship is employed:

$$
T^{I n_{-} M i x} \leq \mathrm{T}^{\text {desired }}+\mathrm{M}^{\mathrm{T}^{\mathrm{In}}}\left(1-y^{E X C_{-} b}\right)
$$

Whereas to activate the binary variable $y^{E X C_{-} c}$, the following relationships are used:

$$
T^{I n \_M i x} \leq \mathrm{T}^{\text {desired }}+\mathrm{M}^{\mathrm{T}^{\mathrm{In}}}\left(1-y^{E X C_{-} c}\right)
$$




$$
T^{I n \_M i x} \geq \mathrm{T}^{\text {desired }}-\mathrm{M}^{\mathrm{T}^{\mathrm{In}}}\left(1-y^{E X C_{-} c}\right)
$$

For the case when the binary variable $y^{E X C_{-} a}$ is set as one, the cooling load $\left(Q^{w w}\right)$ is calculated as follows:

$$
\begin{aligned}
& Q^{c w} \leq m^{I n} C p^{I n \_M i x}\left(T^{I n \_M i x}-\mathrm{T}^{\text {desired }}\right)+\mathrm{M}^{\mathrm{Q}^{\mathrm{ew}}}\left(1-y^{E X C_{-} a}\right) \\
& Q^{c w} \geq m^{I n} C p^{I n \_M i x}\left(T^{I n \_M i x}-\mathrm{T}^{\mathrm{desired}}\right)-\mathrm{M}^{\mathrm{Q}^{\mathrm{Q} w}}\left(1-y^{E X C_{-} a}\right)
\end{aligned}
$$

In order to determine the capital and operating costs associated with the case when cooling is required, the following relationships are required. The operating cost of cooling is calculated as follows:

$$
\begin{aligned}
& \operatorname{Cost}^{c w} \leq \mathrm{UC}^{\mathrm{cw}} Q^{c w}+\mathrm{M}^{\mathrm{cost}^{\mathrm{cw}}}\left(1-y^{E X C_{-} a}\right) \\
& \operatorname{Cost}^{c w} \geq \mathrm{UC}^{\mathrm{cw}} Q^{c w}-\mathrm{M}^{\mathrm{cost}^{\mathrm{w} w}}\left(1-y^{E X C_{-} a}\right)
\end{aligned}
$$

For the capital cost, it is necessary to determine the size of the heat exchanger unit $\left(A^{E X C}\right)$. This is done through the following relationships:

$$
\begin{aligned}
& A^{E X C} \leq \frac{Q^{c w}}{\mathrm{U} L M T D}+\mathrm{M}^{\mathrm{A}}\left(1-y^{E X C_{-} a}\right) \\
& A^{E X C} \geq \frac{Q^{c w}}{\mathrm{U} L M T D}-\mathrm{M}^{\mathrm{A}}\left(1-y^{E X C_{-} a}\right)
\end{aligned}
$$

As can be seen from the previous relationships, it is also necessary to determine the log-mean temperature difference (LMTD). The following relationship is employed for this purpose:

$$
\begin{aligned}
& L M T D \leq \frac{\left(T^{I n_{-} M i x}-T^{O u t_{-} c w}\right)-\left(\mathrm{T}^{\mathrm{desired}}-T^{I n_{-} c w}\right)}{\ln \left(\frac{T^{I n_{-} M i x}-T^{\text {Out_cw }}}{\mathrm{T}^{\mathrm{desired}}-T^{I n_{-} c w}}\right)}+\mathrm{M}^{\mathrm{LMTD}}\left(1-y^{E X C_{-} a}\right) \\
& L M T D \geq \frac{\left(T^{I n_{-} M i x}-T^{O u t_{-} c w}\right)-\left(\mathrm{T}^{\mathrm{desired}_{1}}-T^{I n_{-} c w}\right)}{\ln \left(\frac{T^{I n_{-} M i x}-T^{\mathrm{Out}_{-} c w}}{\mathrm{~T}^{\mathrm{desired}}-T^{I n_{-} c w}}\right)}-\mathrm{M}^{\mathrm{LMTD}}\left(1-y^{E X C_{-} a}\right)
\end{aligned}
$$

Finally, the capital cost for the cooler is calculated as follows: 


$$
\begin{aligned}
& \operatorname{Cost}^{\mathrm{Cool}} \leq \mathrm{A}^{\mathrm{Cool}}+\mathrm{B}^{\mathrm{cool}}\left(A^{E X C}\right)^{\mathrm{C}^{\mathrm{Cool}}}+\mathrm{M}^{\mathrm{Cost}}{ }^{\mathrm{cool}}\left(1-y^{E X C_{-} a}\right) \\
& \operatorname{Cost}^{\mathrm{Cool}} \geq \mathrm{A}^{\mathrm{Cool}}+\mathrm{B}^{\mathrm{cool}}\left(A^{E X C}\right)^{\mathrm{C}^{\mathrm{Coll}}}-\mathrm{M}^{\mathrm{Cost}^{\mathrm{col}}}\left(1-y^{E X C_{-} a}\right)
\end{aligned}
$$

If the binary variable $y^{E X C_{-} b}$ is equal to one, it means that the inlet temperature is lower than the optimal value. Consequently, a heater is required to achieve the desired temperature. Then, the heating load, operating cost, area, log-mean temperature difference and the capital cost are calculated as follows:

$$
\begin{aligned}
& Q^{\text {steam }} \leq m^{I n} C p^{I n_{-} M i x}\left(\mathrm{~T}^{\text {desired }}-T^{I n_{-} M i x}\right)+\mathrm{M}^{\mathrm{Q}^{\text {steam }}}\left(1-y^{E X C_{-} b}\right) \\
& Q^{\text {steam }} \geq m^{I n} C p^{I n_{-} M i x}\left(\mathrm{~T}^{\text {desired }}-T^{I n_{-} M i x}\right)-\mathrm{M}^{\mathrm{Q}^{\text {steam }}}\left(1-y^{E X C_{-} b}\right) \\
& \operatorname{Cost}^{\text {steam }} \leq \mathrm{UC}^{\text {steam }} Q^{\text {steam }}+\mathrm{M}^{\text {cost }}{ }^{\text {steam }}\left(1-y^{E X C_{-} b}\right) \\
& \operatorname{Cost}{ }^{\text {steam }} \geq \mathrm{UC}^{\text {steam }} Q^{\text {steam }}-\mathrm{M}^{\text {cost }}{ }^{\text {steam }}\left(1-y^{E X C_{-} b}\right) \\
& A^{E X C 2} \leq \frac{Q^{\text {steam }}}{\mathrm{U} 2 L M T D}+\mathrm{M}^{\mathrm{A} 2}\left(1-y^{E X C_{-} b}\right) \\
& A^{E X C 2} \geq \frac{Q^{\text {steam }}}{\mathrm{U} 2 L M T D}-\mathrm{M}^{\mathrm{A} 2}\left(1-y^{E X C_{-} b}\right) \\
& L M T D \leq \frac{\left(T^{\text {In_steam }_{-}}-\mathrm{T}^{\text {desired }}\right)-\left(T^{\text {Out_steam }}-T^{\text {In_mix }}\right)}{\ln \left(\frac{T^{\text {In_steam }}-\mathrm{T}^{\text {desired }}}{T^{\text {Out_steam }}-T^{\text {In_mix }}}\right)}+\mathrm{M}^{\mathrm{LMTD}}\left(1-y^{E X C_{-} \mathrm{b}}\right) \\
& L M T D \geq \frac{\left(T^{\text {In_steam }}-\mathrm{T}^{\text {desired }}\right)-\left(T^{\text {Out_steam }}-T^{\text {In_mix }}\right)}{\ln \left(\frac{T^{\text {In_steam }}-\mathrm{T}^{\text {desired }}}{T^{\text {Out_steam }}-T^{\text {In_mix }}}\right)}-\mathrm{M}^{\mathrm{LMTD}}\left(1-y^{E X C_{-} \mathrm{b}}\right)
\end{aligned}
$$

The capital cost is calculated using the following relationships:

$$
\begin{aligned}
& \operatorname{Cost}^{\text {Heat }} \leq \mathrm{A}^{\text {Heat }}+\mathrm{B}^{\text {Heat }}\left(A^{E X C 2}\right)^{\mathrm{C}^{\text {Heat }}}+\mathrm{M}^{\text {Cost }}{ }^{\text {Heat }}\left(1-y^{E X C_{-} b}\right) \\
& \operatorname{Cost}^{\text {Heat }} \geq \mathrm{A}^{\text {Heat }}+\mathrm{B}^{\text {Heat }}\left(A^{E X C 2}\right)^{\mathrm{C}^{\text {Heat }}}-\mathrm{M}^{\text {Cost }{ }^{\text {Heat }}}\left(1-y^{E X C_{-} b}\right)
\end{aligned}
$$


When $y^{E X C_{-} c}$ is equal to one, it means that the inlet temperature to treatment is equal to the optimal temperature. Therefore, it is not necessary to modify the temperature and the costs are set to zero:

$$
Q^{c w} \leq \mathrm{M}^{\mathrm{Q}^{\mathrm{cw}}}\left(1-y^{E X C_{-} c}\right)
$$

$$
Q^{c w} \geq-\mathrm{M}^{\mathrm{Q}^{\mathrm{cw}}}\left(1-y^{E X C_{-} c}\right)
$$

$$
Q^{\text {steam }} \leq \mathrm{M}^{\mathrm{Q}^{\text {steam }}}\left(1-y^{E X C_{-} c}\right)
$$

$$
Q^{\text {steam }} \geq-\mathrm{M}^{\mathrm{Q}^{\text {steam }}}\left(1-y^{E X C_{-} c}\right)
$$

$$
\operatorname{Cost}^{c w} \leq \mathrm{M}^{\text {cost }^{\mathrm{cw}}}\left(1-y^{E X C_{-} c}\right)
$$

$\operatorname{Cost}^{c w} \geq-\mathrm{M}^{\operatorname{cost}^{\mathrm{cw}}}\left(1-y^{E X C_{-} c}\right)$

$\operatorname{Cost}^{\text {steam }} \leq \mathrm{M}^{\text {cost }^{\text {steam }}}\left(1-y^{E X C_{-} c}\right)$

$\operatorname{Cost}^{\text {steam }} \geq-\mathrm{M}^{\text {cost }}{ }^{\text {steam }}\left(1-y^{E X C_{-} c}\right)$

$A^{E X C} \leq \mathrm{M}^{\mathrm{A}}\left(1-y^{E X C_{-} c}\right)$

$A^{E X C} \geq-\mathrm{M}^{\mathrm{A}}\left(1-y^{E X C_{-} c}\right)$

$A^{E X C 2} \leq \mathrm{M}^{\mathrm{A} 2}\left(1-y^{E X C_{-} c}\right)$

$A^{E X C 2} \geq-\mathrm{M}^{\mathrm{A} 2}\left(1-y^{E X C_{-} c}\right)$

$L M T D \leq \mathrm{M}^{\mathrm{LMTD}}\left(1-y^{E X C_{-} c}\right)$

$L M T D \geq-\mathrm{M}^{\mathrm{LMTD}}\left(1-y^{E X C_{-} c}\right)$

$\operatorname{Cost}^{\text {Cool }} \leq \mathrm{M}^{\mathrm{Cost}^{\mathrm{cool}}}\left(1-y^{E X C_{-} c}\right)$

$\operatorname{Cost}^{\text {Cool }} \geq-\mathrm{M}^{\text {Cost }^{\mathrm{cool}}}\left(1-y^{E X C_{-} c}\right)$ 
$\operatorname{Cost}^{\text {Heat }} \leq \mathrm{M}^{\text {Cost }}{ }^{\text {Heat }}\left(1-y^{E X C_{-} c}\right)$

$\operatorname{Cost}^{\text {Heat }} \geq-\mathrm{M}^{\text {Cost }^{\text {Heat }}}\left(1-y^{E X C_{-} c}\right)$

Reverse osmosis

According to the proposed design for the recycle and reuse network, a reverse osmosis unit is placed at the exit of the electrocoagulation process with the purpose of reducing the $\mathrm{NaCl}$ concentration to meet the constraints for the process sinks. In this regard, the existence for this unit is modeled through the following disjunction.

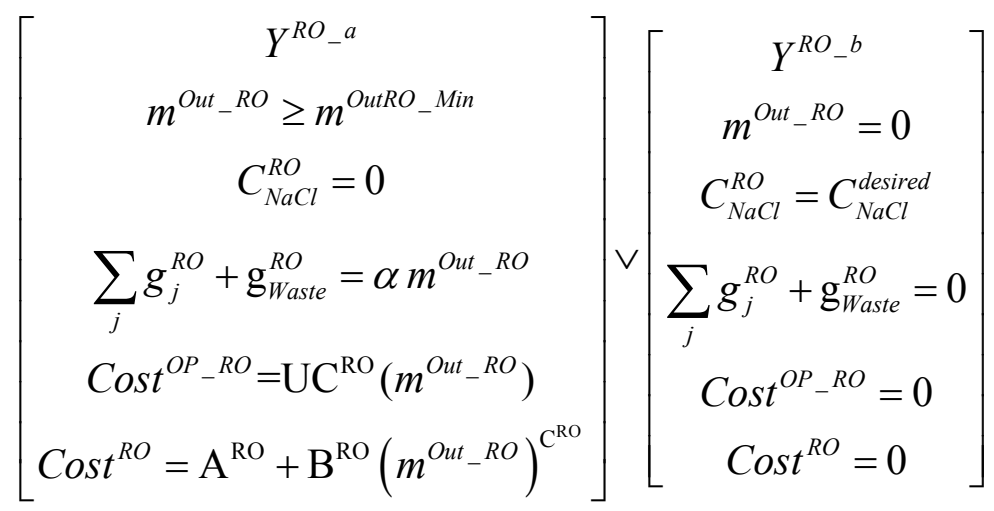

In the previous disjunction, $Y^{R O}{ }^{a}$ represents the Boolean variable associated with the existence of the RO unit; while $Y^{R O-b}$ is the Boolean variable that is set as true when the unit is not required. Then, associated with each Boolean variable there is a binary variable which helps to obtain the following algebraic relationships. Firstly, only one of these two options can be selected:

$$
y^{R O_{-} a}+y^{R O \_b}=1
$$

The next equations are useful to state that if the RO unit is installed, then the outlet stream is free of $\mathrm{NaCl}$; otherwise, if the reverse osmosis is not needed, then the concentration for the stream is fixed in $\mathrm{C}_{\mathrm{NaCl}}^{\text {desired }}$.

$$
\begin{aligned}
& C_{\mathrm{NaCl}}^{R O} \leq \mathrm{M}_{\mathrm{NaCl}}^{\mathrm{RO}}\left(1-y^{R O_{-} a}\right) \\
& C_{\mathrm{NaCl}}^{\mathrm{RO}} \geq-\mathrm{M}_{\mathrm{NaCl}}^{\mathrm{RO}}\left(1-y^{R O_{-} a}\right) \\
& C_{\mathrm{NaCl}}^{R O} \leq C_{\mathrm{NaCl}}^{\text {desired }}+\mathrm{M}_{\mathrm{NaCl}}^{R O}\left(1-y^{R O-b}\right)
\end{aligned}
$$




$$
C_{\text {NaCl }}^{R O} \geq C_{\text {NaCl }}^{\text {desired }}-\mathrm{M}_{\text {NaCl }}^{R O}\left(1-y^{R O \_b}\right)
$$

Furthermore, if the RO unit is required, then the inlet flowrate $\left(m^{\text {Out }} R O\right)$ must be higher than a minimum value to ensure an adequate operation $\left(m^{\text {OutRO_Min }}\right)$; otherwise, if the RO unit is not installed, the inlet flowrate must not exist. This is modeled through the next expressions:

$$
\begin{aligned}
& m^{\text {Out_RO }} \geq m^{\text {OutRO_Min }}-\mathrm{M}^{\text {OutRO_Max }}\left(1-y^{R O_{-} a}\right) \\
& m^{\text {Out_RO }} \leq \mathrm{M}^{\text {OutRO_Max }}\left(1-y^{R O_{-} b}\right) \\
& m^{\text {Out_RO }} \geq-\mathrm{M}^{\text {OutRO_Max }}\left(1-y^{R O{ }_{-} b}\right)
\end{aligned}
$$

According to the proposed disjunction, the next aspect to be modeled is the flowrate leaving the RO unit. In this sense, the reverse osmosis process involves a loss of water, which is considered through the factor $\alpha$. Thus, the remaining water is split and sent to the process $\operatorname{sinks}\left(g_{j}^{R O}\right)$ and to the waste $\left(g_{\text {Waste }}^{R O}\right)$ :

$$
\begin{aligned}
& \sum_{j} g_{j}^{R O}+\mathrm{g}_{\text {Waste }}^{R O} \leq \alpha m^{\mathrm{Out}_{-} R O}+\mathrm{M}^{\mathrm{OutRO} \_ \text {Max }}\left(1-y^{R O_{-} a}\right) \\
& \sum_{j} g_{j}^{R O}+\mathrm{g}_{\text {Waste }}^{R O} \geq \alpha m^{\text {Out_ }_{-} O}-\mathrm{M}^{\text {OutRO_Max }}\left(1-y^{R O_{-} a}\right)
\end{aligned}
$$

On the other hand, if the RO unit is not required, then these streams do not exist, which is modeled as follows:

$$
\begin{aligned}
& \sum_{j} g_{j}^{R O}+\mathrm{g}_{\text {Waste }}^{R O} \leq \mathrm{M}^{\text {OutRO_Max }}\left(1-y^{R O \_b}\right) \\
& \sum_{j} g_{j}^{R O}+\mathrm{g}_{\text {Waste }}^{R O} \geq-\mathrm{M}^{\text {OutRO_Max }}\left(1-y^{R O \_b}\right)
\end{aligned}
$$

The next relationships determine the operating cost for the RO unit:

$$
\begin{aligned}
& \operatorname{Cost}^{O P_{-} R O} \leq \mathrm{UC}^{\mathrm{RO}}\left(m^{\mathrm{Out}_{-} R O}\right)+\mathrm{M}^{\mathrm{OPROCOST}}\left(1-y^{R O_{-} a}\right) \\
& \operatorname{Cost}^{O P_{-} R O} \geq \mathrm{UC}^{\mathrm{RO}}\left(m^{\mathrm{Out}_{-} R O}\right)-\mathrm{M}^{\mathrm{OPROCOST}}\left(1-y^{R O_{-} a}\right)
\end{aligned}
$$




$$
\begin{aligned}
& \operatorname{Cost}^{O P_{-} R O} \leq \mathrm{M}^{\mathrm{OPROCOST}}\left(1-y^{R O_{-} b}\right) \\
& \text { Cost }^{O P_{-} R O} \geq-\mathrm{M}^{\mathrm{OPROCOST}}\left(1-y^{R O_{-} b}\right)
\end{aligned}
$$

The capital cost is calculated considering fixed and variable charges as follows:

$$
\begin{aligned}
& \operatorname{Cost}^{R O} \leq \mathrm{A}^{\mathrm{RO}}+\mathrm{B}^{\mathrm{RO}}\left(m^{\mathrm{Out}_{-} R O}\right)^{\mathrm{C}^{\mathrm{RO}}}+\mathrm{M}^{\mathrm{RO}}\left(1-y^{R O_{-} a}\right) \\
& \operatorname{Cost}^{R O} \geq \mathrm{A}^{\mathrm{RO}}+\mathrm{B}^{\mathrm{RO}}\left(m^{\text {Out }_{-} R O}\right)^{\mathrm{C}^{\mathrm{RO}}}-\mathrm{M}^{\mathrm{RO}}\left(1-y^{R O_{-} a}\right) \\
& \operatorname{Cost}^{R O} \leq \mathrm{M}^{\mathrm{RO}}\left(1-y^{R O_{-} b}\right) \\
& \operatorname{Cost}^{R O} \geq-\mathrm{M}^{\mathrm{RO}}\left(1-y^{R O_{-} b}\right)
\end{aligned}
$$

It should be noted that the operating and capital costs depend of the treated flowrate.

\section{Electrocoagulation}

For the purpose of properly modelling the electrocoagulation system, the experimental data by Abdelwahab et al. ${ }^{1}$ were used. First, the optimal desired for the wastewater treatment system were matched with the experimentally found results of Abdelwahab et al. ${ }^{1}$ (in this case the best conditions were the following: $\mathrm{NaCl}$ concentration: $2 \mathrm{~kg} / \mathrm{m}^{3}, \mathrm{pH}: 7$, time: $2 \mathrm{~h}$, c.d: $19.3 \mathrm{~mA} / \mathrm{cm}^{2}$, and temperature: $293 \mathrm{~K})$. The energy required and aluminum consumption are the key factors used to determine the electrocoagulation cost in optimization. By analyzing the experimental data of Abdelwahab et al. ${ }^{1}$, these two aspects can be correlated with the initial phenol concentration (Figure 3). Thus, the energy and aluminum consumption are determined directly through the initial phenol concentration.

As can be seen from Figure 3, the initial phenol concentration is a key factor for modeling the electrocoagulation unit and in the optimization formulation this is modeled through the following disjunction: 


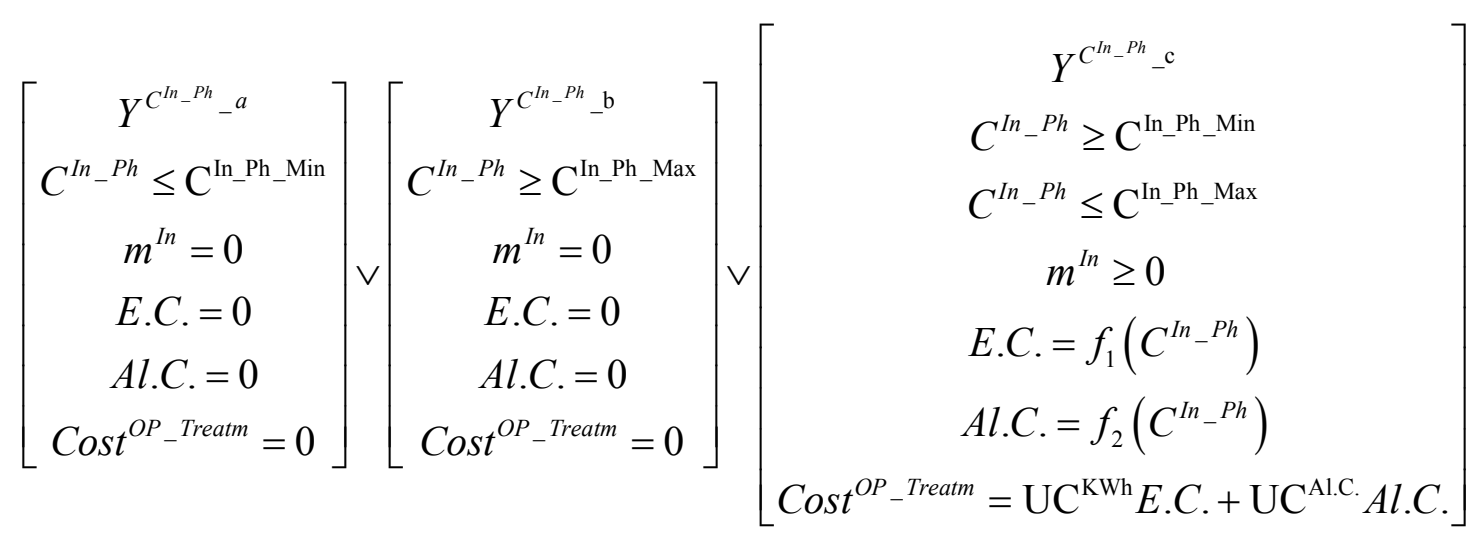

In the previous disjunction, three options are considered. The first one (associated with the Boolean variable $Y^{C^{I_{-}{ }^{P h}}{ }_{-}{ }^{a}}$ ) represents the case when the initial phenol concentration is lower than the minimum allowed $\left(\mathrm{C}^{\mathrm{In} \_\mathrm{Ph} \_ \text {Min }}\right)$, the second option (associated with the Boolean variable $Y^{C^{I_{-} P^{P h}}{ }_{-}^{\mathrm{b}}}$ ) represents the case when the initial phenol concentration is greater than the maximum allowed $\left(\mathrm{C}^{\mathrm{In} \_\mathrm{Ph}-\mathrm{Max}}\right)$. In these two options, the electrocoagulation unit is not used and the associated operating cost must be zero. In the third scenario (associated with the Boolean variable $Y^{C^{I_{-} P^{P h}}{ }_{-} \mathrm{c}}$ ), the electrocoagulation unit is required, and the corresponding energy (E.C.) and aluminum (Al.C.) consumed are calculated to determine the associated operating cost $\left(\operatorname{Cost}^{O P}{ }_{-}^{\text {Treatm }}\right)$. Again, the disjunction is reformulated as a set of algebraic constraints as follows. First, only one option must be selected:

$$
y^{C^{I n_{-} P h}-{ }^{a}}+y^{C^{I n_{-} P h}-\mathrm{b}}+y^{C^{I n_{-} P h}{ }_{-}^{\mathrm{c}}}=1
$$

The binary variables are activated through the following relationships:

$$
\begin{aligned}
& C^{I n_{-} P h} \leq \mathrm{C}^{\mathrm{In}_{-} \mathrm{Ph}{ }_{-} \mathrm{Min}}+\mathrm{M}^{\mathrm{Ph}}\left(1-y^{\mathrm{C}^{\mathrm{In}_{-} P h_{-}} a}\right) \\
& C^{I n_{-} P h} \geq \mathrm{C}^{\mathrm{In}{ }_{-} \mathrm{Ph}{ }_{-} \mathrm{Max}}-\mathrm{M}^{\mathrm{Ph}}\left(1-y^{C^{\mathrm{In}_{-} P h}-\mathrm{b}}\right) \\
& C^{I n_{-} P h} \geq \mathrm{C}^{\mathrm{In}{ }_{-} \mathrm{Ph}{ }_{-} \mathrm{Min}}-\mathrm{M}^{\mathrm{Ph}}\left(1-y^{\mathrm{C}^{I n_{-} P h}{ }_{-}{ }^{c}}\right) \\
& C^{I n_{-} P h} \leq \mathrm{C}^{\mathrm{In}_{-} \mathrm{Ph}{ }_{-} \mathrm{Max}}+\mathrm{M}^{\mathrm{Ph}}\left(1-y^{\mathrm{C}^{\mathrm{In}{ }_{-} P h}{ }_{-} c}\right)
\end{aligned}
$$

The upper limits for the variables involved in the first section of the disjunction are set as follows: 


$$
\begin{aligned}
& m^{I n} \leq \mathrm{M}^{\mathrm{m}^{\mathrm{In}}}\left(1-y^{\mathrm{C}^{I n_{-} P h}-a}\right) \\
& m^{I n} \geq-\mathrm{M}^{\mathrm{m}^{\mathrm{In}}}\left(1-y^{\mathrm{C}^{\mathrm{In}_{-} P h}-a}\right) \\
& \text { E.C. } \leq \mathrm{M}^{\text {E.C. }}\left(1-y^{C^{I_{-}{ }^{P h}}{ }_{-} a}\right) \\
& \text { E.C. } \geq-\mathrm{M}^{\mathrm{E} . \mathrm{C} .}\left(1-y^{\mathrm{Cln}_{-}{ }^{P h}{ }_{-} a}\right) \\
& \text { Al.C. } \leq \mathrm{M}^{\mathrm{Al.C.}}\left(1-y^{\mathrm{Cl}_{-}^{l_{P} P h}{ }_{-} a}\right) \\
& \text { Al.C. } \geq-\mathrm{M}^{\text {Al.C. }}\left(1-y^{C^{l_{-} P h}-a}\right) \\
& \operatorname{Cost}^{\mathrm{OP}_{-} \text {Treatm }} \leq \mathrm{M}^{\mathrm{Cost}^{\mathrm{OP}_{-} \mathrm{Treatm}}}\left(1-y^{\mathrm{C}^{\mathrm{In}_{-} P_{-}}{ }^{a}}\right) \\
& \operatorname{Cost}^{\mathrm{OP}_{-} \text {Treatm }} \geq-\mathrm{M}^{\mathrm{Cost}^{\mathrm{OP}_{-} \text {Treatm }}}\left(1-y^{\mathrm{Cln}_{-}^{\mathrm{P}_{-}{ }_{-} a}}\right)
\end{aligned}
$$

The upper limits for the second section of the disjunction are stated as follows:

$$
\begin{aligned}
& m^{I n} \leq \mathrm{M}^{\mathrm{m}^{\mathrm{In}}}\left(1-y^{\mathrm{C}^{I_{-} P h}-b}\right) \\
& m^{I n} \geq-\mathrm{M}^{\mathrm{m}^{\mathrm{In}}}\left(1-y^{C^{I_{-} P h}-b}\right) \\
& \text { E.C. } \leq \mathrm{M}^{\text {E.C. }}\left(1-y^{\mathrm{C}^{\mathrm{In}_{-} P h}-{ }_{-}}\right) \\
& \text {E.C. } \geq-\mathrm{M}^{\mathrm{E} . \mathrm{C} .}\left(1-y^{\mathrm{C}_{-}^{I n_{-}{ }^{P h}}-b}\right) \\
& \text { Al.C. } \leq \mathrm{M}^{\mathrm{Al.C.}}\left(1-y^{\mathrm{C}^{I n_{-} P h}{ }_{-} b}\right) \\
& \text { Al.C. } \geq-\mathrm{M}^{\mathrm{Al} . C .}\left(1-y^{\mathrm{C}_{-}^{I n_{-} P h}-b}\right) \\
& \mathrm{Cost}^{\mathrm{OP}_{-} \text {Treatm }} \leq \mathrm{M}^{\mathrm{Cost}^{\mathrm{OP}_{-} \mathrm{Treatm}}}\left(1-y^{\mathrm{Cln}_{-}^{\mathrm{In}_{-}{ }_{-}}}\right) \\
& \mathrm{Cost}^{\mathrm{OP}_{-} \text {Treatm }} \geq-\mathrm{M}^{\mathrm{Cost}^{\mathrm{OP}_{-} \text {Treatm }}}\left(1-y^{\mathrm{C}^{\mathrm{ln}-\mathrm{Ph}}-b}\right)
\end{aligned}
$$

The relationships for the last section are stated as follows: 
E.C. $\leq-1.1917 \times 10^{-7}\left(C^{I n_{-} P h}\right)^{3}+6.5373 \times 10^{-5}\left(C^{I n_{-} P h}\right)^{2}-1.1315 \times 10^{-2}\left(C^{I n}{ }_{-}^{P h}\right)+0.7793+M^{A l . C .}\left(1-y^{C^{I n_{-} P h}{ }_{-}{ }^{c}}\right)$

E.C. $\geq-1.1917 \times 10^{-7}\left(C^{I n_{-} P h}\right)^{3}+6.5373 \times 10^{-5}\left(C^{I n_{-} P h}\right)^{2}-1.1315 \times 10^{-2}\left(C^{I n_{-} P h}\right)+0.7793-M^{A l . C .}\left(1-y^{C^{I n_{-} P h}{ }_{-}{ }^{c}}\right)$

Al.C. $\leq 2.8521 \times 10^{-8}\left(C^{I n_{-} P h}\right)^{3}-4.2077 \times 10^{-6}\left(C^{I n_{-} P h}\right)^{2}+8.6930 x 10^{-4}\left(C^{I n_{-} P h}\right)+0.1676+M^{E . C .}\left(1-y^{C^{l n_{-} P h}{ }_{-}{ }^{c}}\right)$

Al.C. $\geq 2.8521 \times 10^{-8}\left(C^{I n_{-} P h}\right)^{3}-4.2077 \times 10^{-6}\left(C^{I n_{-} P h}\right)^{2}+8.6930 \times 10^{-4}\left(C^{I n_{-} P h}\right)+0.1676-M^{E . C .}\left(1-y^{C^{I n}{ }_{-}^{P h}}{ }_{-}{ }^{c}\right)$

$\operatorname{Cost}^{\mathrm{OP}_{-}{ }_{\text {Treatm }}} \leq \mathrm{UC}^{\mathrm{KWh}}$ E.C. $+\mathrm{UC}^{\text {Al.C. }}$ Al.C. $+\mathrm{M}^{\mathrm{Cost}^{\mathrm{OP}_{-} \mathrm{Treatm}}}\left(1-y^{\mathrm{C}^{\mathrm{In}_{-} P h}{ }_{-} c}\right)$

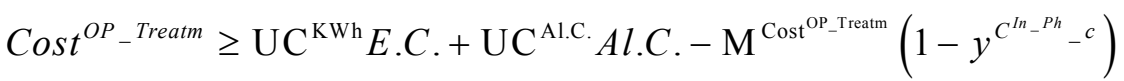

It should be noted that the removal efficiency for the electrocoagulation system, $\gamma$, is determined experimentally and depends on the following functionality:

$\gamma=f\left(p H, I, C^{I n+P h}, C^{N a C l}, T\right)$

Notice that the desired conditions determined experimentally for the electrocoagulation system were considered; however, the initial phenol concentration is the only optimization variable in the formulation. This is modeled employing the correlation shown in Figure 4.

$\gamma=\frac{-0.3005 C^{I n_{-} P h}+108.74}{100}$

The outlet phenol concentration from the electrocoagulation unit is determined as follows:

$P_{C^{P h}}^{\text {Out }}=P_{C^{P h}}^{I n}(1-\gamma)$

Finally, the capital cost for the entire electrocoagulation unit $\left(\right.$ Cost $\left.^{\text {Treatm }}\right)$ depends on the flowrate treated as follows:

$$
\begin{aligned}
& \operatorname{Cost}^{\text {Treatm }} \leq \mathrm{M}^{\text {Cost }^{\text {Treatm }}}\left(1-y^{C^{I_{-} P_{-}}{ }^{a}}\right) \\
& \operatorname{Cost}^{\text {Treatm }} \geq-\mathrm{M}^{\text {Cost }^{\text {Treatm }}}\left(1-y^{C^{I_{-} P_{-}{ }_{-} a}}\right)
\end{aligned}
$$




$$
\begin{aligned}
& \operatorname{Cost}^{\text {Treatm }} \leq \mathrm{M}^{\text {Cost }^{\text {Treatm }}}\left(1-y^{C^{I_{n} P_{-}}{ }_{-}^{b}}\right)
\end{aligned}
$$

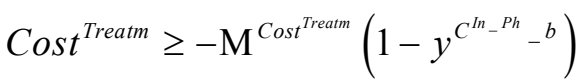

$$
\begin{aligned}
& \operatorname{Cost}^{\text {Treatm }} \leq \mathrm{A}^{\text {Treatm }}+\mathrm{B}^{\text {Treatm }}\left(m^{I n}\right)^{\mathrm{C}^{\text {Treatm }}}+\mathrm{M}^{\text {Cost }^{\text {Treatm }}}\left(1-y^{C^{I_{-}{ }^{P h}}{ }_{-} c}\right) \\
& \operatorname{Cost}^{\text {Treatm }} \geq \mathrm{A}^{\text {Treatm }}+\mathrm{B}^{\text {Treatm }}\left(m^{I n}\right)^{\mathrm{C}^{\text {Treatm }}}-\mathrm{M}^{\text {Cost }^{\text {Treatm }}}\left(1-y^{C^{\text {In }_{-}{ }^{P h}}{ }_{-}{ }^{c}}\right)
\end{aligned}
$$

\section{Objective function}

The total annualized cost is the sum of the total operating costs including the fresh water cost $\left(F_{r} \mathrm{UC}^{\mathrm{Fresh}}\right)$ and the costs associated with operate each unit required plus the annualized capital costs for the units involved in the treatment.

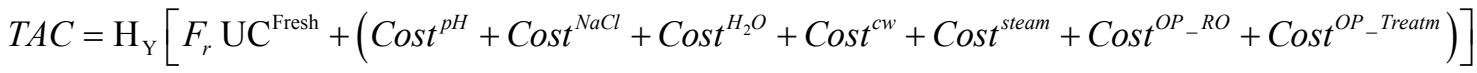

$$
\begin{aligned}
& +\mathrm{k}_{\mathrm{F}}\left(\operatorname{Cost}^{\text {Cool }}+\operatorname{Cost}^{\text {Heat }}+\operatorname{Cost}^{\text {Treatm }}+\operatorname{Cost}^{\text {RO }}\right)
\end{aligned}
$$

In the previous equation, $\mathrm{H}_{\mathrm{Y}}$ represents the operating hours $(8000 \mathrm{~h} /$ year $)$ and $\mathrm{k}_{\mathrm{F}}$ corresponds to the annualization factor for the depreciation of capital cost. It should be noted that the corresponding optimization formulation is a mixed-integer nonlinear programming (MINLP) problem, which was coded in the GAMS software. ${ }^{2}$

\section{S2. NOMENCLATURE}

\section{Variables}

$\begin{array}{ll}\text { Acid } & \text { Acid added in treatment } \\ A^{E X C} & \text { Cooler's area } \\ A^{E X C 2} & \text { Heater's area } \\ \text { Al.C. } & \text { Aluminum consumed } \\ \text { Base } & \text { Base added in treatment } \\ C_{\text {NaCl }}^{\text {In-Mix }} & \text { NaCl concentration inlet to MIX-1 } \\ C^{\text {NaCl }} & \text { NaCl concentration } \\ C^{\text {In_Mix }} & \text { Heat capacity }\end{array}$




\begin{tabular}{|c|c|}
\hline$C^{I n_{-} \mathrm{Ph}}$ & Phenol concentration \\
\hline $\mathrm{Cost}^{\mathrm{OP}-\mathrm{Tratm}}$ & Operating treatment cost \\
\hline Cost Treatm $^{\text {Tre }}$ & Treatment cost \\
\hline $\operatorname{Cost}^{\text {steam }}$ & Steam cost \\
\hline $\operatorname{Cos} t^{c w}$ & Cooling cost \\
\hline Cost ${ }^{\text {Heat }}$ & Heater cost \\
\hline $\operatorname{Cost}^{\mathrm{NaCl}}$ & $\mathrm{NaCl}$ cost \\
\hline $\mathrm{Cost}^{\mathrm{H}_{2} \mathrm{O}}$ & Fresh water cost \\
\hline $\operatorname{Cost}^{p H}$ & $\mathrm{pH}$ adjust cost \\
\hline Cost ${ }^{\text {cool }}$ & Cooler cost \\
\hline $\mathrm{Cost}^{\mathrm{OP}-\mathrm{RO}}$ & Operating cost for reverse osmosis \\
\hline Cost $^{R O}$ & Reverse osmosis unit cost \\
\hline E.C. & Energy consumed \\
\hline$F_{r}$ & Total flowrate of fresh sources $r$ \\
\hline$f_{r, j}$ & Segregated flowrate from fresh source $r$ to sink $j$ \\
\hline$g_{\text {Waste }}$ & Segregated flowrate from treatment to waste \\
\hline$g_{\text {Waste }}^{R O}$ & Segregated flowrate from $\mathrm{RO}$ to waste \\
\hline$g_{j}$ & Segregated flowrate from treatment to sink $\mathrm{j}$ \\
\hline$g_{j}^{R O}$ & Segregated flowrate from $\mathrm{RO}$ to sink $\mathrm{j}$ \\
\hline$h_{i}$ & Segregated flowrate from sources to treatment \\
\hline$L M T D$ & Logarithmic mean temperature difference \\
\hline$m^{I n}$ & Total flowrate from sources to treatment \\
\hline$m^{\text {Out }}$ & Total flowrate from treatment to sinks \\
\hline
\end{tabular}




$\begin{array}{ll}m^{\text {NaCl }} & \text { Total flowrate of NaCl added in treatment } \\ m^{\text {Fresh }} & \text { Total flowrate of fresh water added in treatment } \\ m^{\text {Out_RO }} & \text { Total flowrate from RO to sinks } \\ m^{\text {OutRO_Min }} & \text { Minimum total flowrate from RO to sinks } \\ m^{\text {OutRO_Max }} & \text { Maximum total flowrate from RO to sinks } \\ p H^{\text {In_Mix }} & \text { pH inlet to MIX-1 } \\ Q^{\text {cw }} & \text { Heat removed } \\ Q^{\text {steam }} & \text { Heat added } \\ T^{\text {In_Mix }} & \text { Temperature inlet to MIX-1 } \\ w_{i, j} & \text { Segregated flowrate from souses to sinks } \\ w_{i, \text { waste }} & \text { Segregated flowrate from sources to waste } \\ \text { Waste } & \text { Total flowrate for the waste stream discharged to the environment } \\ \text { TAC } & \text { Total annual cost }\end{array}$

Parameters
A
Constant for the cost estimation
B
Constant for the cost estimation
$\mathrm{C}$
Constant for the cost estimation
Conc $^{\text {Acid }}$
Acid concentration
Conc ${ }^{\text {Base }}$
Base concentration
$\mathrm{C}_{\mathrm{NaCl}}^{\text {desired }}$
Desired $\mathrm{NaCl}$ concentration for electrocoagulation process
$\mathrm{C}^{\mathrm{In} \_ \text {Ph_Max }} \quad$ Maximum concentration of phenol
$\mathrm{C}^{\mathrm{In} \_ \text {Ph_Min }} \quad$ Minimum concentration of phenol
$\mathrm{G}_{\mathrm{j}}^{\text {Sink }}$
Total flowrate inlet to sink $\mathrm{j}$ 


$\begin{array}{ll}\mathrm{H}_{\mathrm{Y}} & \text { Time of operation of the plant in h/year } \\ \mathrm{k}_{\mathrm{F}} & \text { Factor used to annualize the inversion } \\ \mathrm{pH}_{\text {desired }} & \text { Desired } \mathrm{pH} \text { for electrocoagulation process } \\ \mathrm{U} & \text { Global heat transfer coefficient } \\ \mathrm{UC}^{\text {Acid }} & \text { Unit cost for acid in treatment } \\ \mathrm{UC}^{\text {Al.C. }} & \text { Unit cost for aluminum anode } \\ \mathrm{UC}^{\text {Base }} & \text { Unit cost for base in treatment } \\ \mathrm{UC}^{\mathrm{cw}} & \text { Unit cost for coolant in treatment } \\ \mathrm{UC}^{\text {Fresh }} & \text { Unit cost for fresh water } \\ \mathrm{UC}^{\mathrm{H}_{2} \mathrm{O}} & \text { Unit cost for fresh water in treatment } \\ \mathrm{UC}^{\mathrm{KWh}} & \text { Unit cost for electricity } \\ \mathrm{UC}^{\mathrm{NaCl}} & \text { Unit cost for sodium chloride } \\ \mathrm{UC}^{\mathrm{RO}} & \text { Unit cost for treating wastewater in reverse osmosis } \\ \mathrm{UC}^{\text {steam }} & \text { Unit cost for the steam } \\ \mathrm{T}^{\text {desired }} & \text { Desired temperature for the electrocoagulation process } \\ \mathrm{W}_{\mathrm{i}} & \text { Total flowrate for the process source i }\end{array}$

\section{Greek symbols}
$\alpha \quad$ Efficiency factor for the reverse osmosis process
$\beta \quad$ Efficiency factor for the electrocoagulation process
$\gamma \quad$ Efficiency factor for phenol removal in electrocoagulation process
$\rho^{I n-M i x} \quad$ Inlet treatment density
$\psi_{p}^{I n M I x}(P) \quad$ Properties for the streams inlet to the treatment unit
$\psi_{p, i}^{\text {Source }}(P) \quad$ Properties of the streams from the different process sources


$\psi_{p, j}^{\text {Sink }}(P) \quad$ Property operator for the sinks

$\psi_{\mathrm{p}, \mathrm{j}}^{\text {Sink_Max }}(\mathrm{P}) \quad$ Maximum for the property operator for the sinks

$\psi_{\mathrm{p}, \mathrm{j}}^{\text {Sink_Min }}(\mathrm{P}) \quad$ Minimum for the property operator for the sinks

$\psi_{\mathrm{p}, \text { waste }}^{\text {Sink_Max }}(\mathrm{P}) \quad$ Maximum for the property operator for the waste

$\psi_{\mathrm{p}, \text { waste }}^{\text {Sink_Min }}(\mathrm{P}) \quad$ Minimum for the property operator for the waste

$\psi_{p, r}^{\text {Fresh }}(P) \quad$ Property operator for fresh sources

$\psi_{p}^{\text {OutSplit }}(P) \quad$ Property operator for treated wastewater

$\psi_{p}^{R O}(P) \quad$ Property operator for reverse osmosis outlet stream

\section{Big M Parameters}

$\begin{array}{ll}\mathrm{M}^{\mathrm{pH}} & \mathrm{pH} \text { adjustment } \\ \mathrm{M}^{\text {Base }} & \text { Mass of base } \\ \mathrm{M}^{\text {cost }^{\mathrm{HH}}} & \mathrm{pH} \text { adjustment cost } \\ \mathrm{M}^{\mathrm{Acid}} & \text { Mass of acid } \\ \mathrm{M}^{\mathrm{C}^{\mathrm{NaCl}}} & \text { NaCl concentration } \\ \mathrm{M}^{\mathrm{NaCl}} & \text { Mass of NaCl } \\ \mathrm{M}^{\text {cost }}{ }^{\mathrm{NaCl}} & \text { NaCl concentration adjustment cost } \\ \mathrm{M}^{\mathrm{Fresh}} & \text { Mass of fresh water } \\ \mathrm{M}^{\text {cost }}{ }^{\mathrm{H} \mathrm{O}} & \text { NaCl concentration adjustment cost } \\ \mathrm{M}^{\mathrm{T}^{\mathrm{In}}} & \text { Inlet temperature adjustment } \\ \mathrm{M}^{\mathrm{Q}^{\mathrm{cw}}} & \text { Heat removal } \\ \mathrm{M}^{\text {cost }} & \text { Heat removal cost } \\ \mathrm{M}^{\mathrm{A}} & \text { Cooler area }\end{array}$




\begin{tabular}{|c|c|}
\hline $\mathrm{M}^{\mathrm{LMTD}}$ & Logarithmic mean temperature \\
\hline $\mathrm{M}^{\mathrm{cost} \mathrm{cool}^{\operatorname{col}}}$ & Cooler cost \\
\hline $\mathrm{M}^{\mathrm{Q}^{\text {steam }}}$ & Adding heat \\
\hline $\mathrm{M}^{\operatorname{cost}^{\text {steam }}}$ & Heating cost \\
\hline $\mathrm{M}^{\mathrm{A} 2}$ & Heater area \\
\hline $\mathrm{M}^{\text {cost }}{ }^{\text {Heat }}$ & Heater cost \\
\hline $\mathrm{M}_{\mathrm{NaCl}}^{\mathrm{RO}}$ & $\mathrm{NaCl}$ concentration in reverse osmosis \\
\hline $\mathrm{M}^{\text {cost }}{ }^{\text {Outro_Max }}$ & Inlet flowrate to reverse osmosis \\
\hline $\mathrm{M}^{\mathrm{OPROCOST}}$ & Operating cost of the reverse osmosis unit \\
\hline $\mathrm{M}^{\mathrm{RO}}$ & Capital cost of reverse osmosis \\
\hline $\mathrm{M}^{\mathrm{Ph}}$ & Phenol concentration \\
\hline $\mathrm{M}^{\mathrm{m}^{\mathrm{In}}}$ & Inlet flow to treatment \\
\hline $\mathrm{M}^{\mathrm{E.C} .}$ & Energy consumption \\
\hline $\mathrm{M}^{\mathrm{Al.C} .}$ & Aluminum consumption \\
\hline $\mathrm{M}^{\text {costOP_Treatm }}$ & Operating cost of treatment \\
\hline $\mathrm{M}^{\text {cost }^{\mathrm{Treatm}}}$ & Capital cost of treatment \\
\hline
\end{tabular}

\section{Boolean Variables}

$Y^{p H \_a} \quad$ Logic variable for case a for $\mathrm{pH}$ adjustment

$Y^{p H_{-} b} \quad$ Logic variable for case $\mathrm{b}$ for $\mathrm{pH}$ adjustment

$Y^{p H_{-} c} \quad$ Logic variable for case $\mathrm{c}$ for $\mathrm{pH}$ adjustment

$\mathrm{Y}^{\mathrm{NaCl} \_} \quad$ Logic variable for case a for $\mathrm{NaCl}$ concentration adjustment

$\mathrm{Y}^{\mathrm{NaCl} \_} \quad$ Logic variable for case $\mathrm{b}$ for $\mathrm{NaCl}$ concentration adjustment 
$Y^{\mathrm{NaCl} \_} \quad$ Logic variable for case $\mathrm{b}$ for $\mathrm{NaCl}$ concentration adjustment

$Y^{E X C_{-} a} \quad$ Logic variable for case a for temperature adjustment

$Y^{E X C_{-} b} \quad$ Logic variable for case $\mathrm{b}$ for temperature adjustment

$Y^{E X C_{-} c} \quad$ Logic variable for case $\mathrm{c}$ for temperature adjustment

$Y^{R O \_a} \quad$ Logic variable for case a for reverse osmosis process

$Y^{R O \_} \quad \quad$ Logic variable for case $\mathrm{b}$ for reverse osmosis process

$Y^{I h_{-} P h_{-} a} \quad$ Logic variable for case a for electrocoagulation process

$Y^{h_{-} P h_{-} b} \quad$ Logic variable for case $\mathbf{b}$ for electrocoagulation process

$Y^{I_{-} P h_{-} c} \quad$ Logic variable for case $\mathrm{c}$ for electrocoagulation process

\section{Subscripts and superscripts}

$\begin{array}{ll}\text { Max } & \text { Maximum } \\ \text { Min } & \text { Minimum } \\ \text { In } & \text { Inlet } \\ \text { Out } & \text { Outlet } \\ \text { Cool } & \text { Cooler } \\ \text { Heat } & \text { Heater } \\ \text { RO } & \text { Reverse osmosis } \\ \text { Treat } & \text { Treatment } \\ \text { desired } & \text { Desired value }\end{array}$

\section{Indices}

$\begin{array}{ll}\mathrm{i} & \text { Process source } \\ \mathrm{j} & \text { Sink } \\ \mathrm{p} & \text { Property }\end{array}$


r $\quad$ Fresh source

Waste Waste stream

\section{S3. RESULTS AND PARAMETERS}

This section presents complementary tables that provide the entire results and the parameters used for solving the presented case studies.

Table S1. Flowrate and property constrains for the sinks for case study 1.

\begin{tabular}{|c|c|c|c|c|c|c|c|}
\hline \multirow{2}{*}{$\mathbf{G}_{\mathbf{j}}$} & \multirow{2}{*}{ Flow $\left(\mathrm{m}^{3} / \mathrm{h}\right)$} & \multirow{2}{*}{$\begin{array}{c}\text { Phenol (mg/l) } \\
\text { Max }\end{array}$} & \multicolumn{2}{|c|}{ pH } & \multirow{2}{*}{$\begin{array}{c}\mathrm{NaCl}\left(\mathrm{kg} / \mathrm{m}^{3}\right) \\
\mathrm{Max}\end{array}$} & \multicolumn{2}{|c|}{ Temperature (K) } \\
\hline & & & Min & Max & & Min & $\operatorname{Max}$ \\
\hline 1 & 60 & 5 & 6.7 & 8.2 & 2.0 & 300.00 & 305.00 \\
\hline 2 & 160 & 10 & 6.5 & 8.5 & 3.0 & 300.00 & 305.00 \\
\hline 3 & 80 & 3 & 6 & 8 & 1.0 & 295.00 & 300.00 \\
\hline 4 & 70 & 13 & 7 & 7.8 & 0.9 & 295.00 & 298.00 \\
\hline Waste & - & 1 & 6 & 8 & 2.0 & 293.00 & 303.00 \\
\hline
\end{tabular}

Table S2. Segregated flowrates from sources, fresh water, treatment unit, and RO to the sinks and waste for case study 1.

\begin{tabular}{|c|c|c|c|c|c|c|c|c|c|c|c|}
\hline \multirow{2}{*}{$\mathbf{G}_{\mathbf{j}}$} & \multirow{2}{*}{$\begin{array}{l}\text { Fresh source } \\
\qquad\left(\mathbf{m}^{3} / \mathbf{h}\right)\end{array}$} & \multirow{2}{*}{$\begin{array}{l}\text { Treatment unit } \\
\qquad\left(\mathrm{m}^{3} / \mathbf{h}\right)\end{array}$} & \multicolumn{8}{|c|}{ Sources $\left(\mathrm{m}^{3} / \mathbf{h}\right)$} & \multirow{2}{*}{$\begin{array}{l}\text { Total } \\
\left(\mathrm{m}^{3} / \mathrm{h}\right)\end{array}$} \\
\hline & & & $W_{1}$ & $W_{2}$ & $\boldsymbol{W}_{3}$ & $\boldsymbol{W}_{4}$ & $W_{5}$ & $W_{6}$ & $\boldsymbol{W}_{7}$ & $W_{8}$ & \\
\hline 1 & 0 & 23.70 & 0 & 0 & 30.60 & 0 & 0 & 0 & 0 & 5.72 & 60.0 \\
\hline 2 & 0 & 0 & 0 & 0 & 46.09 & 3.15 & 39.43 & 0 & 50.47 & 20.86 & 160.0 \\
\hline 3 & 25.00 & 25.00 & 0 & 0 & 30.00 & 0 & 0 & 0 & 0 & 0 & 80.0 \\
\hline 4 & 26.01 & 25.95 & 6.31 & 3.15 & 8.59 & 0 & 0 & 0 & 0 & 0 & 70.0 \\
\hline Waste & - & 209.21 & 0 & 21.19 & 0 & 0 & 0 & 0 & 0 & 0 & 230.4 \\
\hline
\end{tabular}


Table S3. Sink and waste properties for case study 1.

\begin{tabular}{cccccc}
\hline $\mathbf{G}_{\mathbf{j}}$ & Flow $\left(\mathbf{m}^{\mathbf{3}} / \mathbf{h}\right)$ & Phenol $(\mathbf{m g} / \mathbf{l})$ & $\mathbf{p H}$ & $\mathbf{N a C l ~}\left(\mathbf{k g} / \mathbf{m}^{\mathbf{3}}\right)$ & Temperature $(\mathbf{K})$ \\
\hline 1 & 60 & 5 & 7.75 & 1.0 & 303.00 \\
\hline 2 & 160 & 10 & 7.80 & 2.0 & 312.82 \\
\hline 3 & 80 & 0.756 & 6.98 & 1.0 & 300.00 \\
\hline 4 & 70 & 3.214 & 7.08 & 0 & 297.00 \\
\hline Waste & 230.4 & 1 & 7.97 & 2.0 & 294.56 \\
\hline
\end{tabular}

Table S4. Flowrate from sources to treatment for case study 1.

\begin{tabular}{cccccc}
\hline $\mathbf{h}_{\mathbf{i}}$ & Flow $\left(\mathbf{m}^{\mathbf{3}} / \mathbf{h}\right)$ & Phenol $(\mathbf{m g} / \mathbf{l})$ & $\mathbf{p H}$ & $\mathbf{N a C l}\left(\mathbf{k g} / \mathbf{m}^{\mathbf{3}}\right)$ & Temperature $(\mathbf{K})$ \\
\hline 3 & 21.271 & 1.2 & 8.0 & 1.0 & 310.00 \\
\hline 6 & 11.040 & 8.5 & 6.8 & 3.0 & 298.00 \\
\hline 8 & 257.330 & 42 & 7.0 & 2.0 & 307.00 \\
\hline Total & $\mathbf{2 8 9 . 6 4 0}$ & $\mathbf{3 7 . 7 3}$ & $\mathbf{7 . 2 2}$ & $\mathbf{2 . 0}$ & $\mathbf{3 0 6 . 8 8}$ \\
\hline
\end{tabular}

Table S5. Flowrate in the electrocoagulation treatment system for case study 1.

\begin{tabular}{lccccc}
\hline Flow $\left(\mathbf{m}^{\mathbf{3}} / \mathbf{h}\right)$ & $\begin{array}{c}\text { Phenol } \\
(\mathbf{m g} / \mathbf{l})\end{array}$ & $\mathbf{p H}$ & $\begin{array}{c}\mathbf{N a C l} \\
\mathbf{( k g / \mathbf { m } ^ { 3 } )}\end{array}$ & Temperature (K) \\
\hline $\begin{array}{c}\text { In } \\
\mathbf{m}\end{array}$ & 289.64 & 37.73 & 7.22 & 2.0 & 306.88 \\
\hline $\begin{array}{l}\text { Out } \\
\mathbf{m}\end{array}$ & 283.85 & 0.98 & 8 & 2.0 & 293.00
\end{tabular}


Table S6. Flowrate and properties constrains for the sinks and waste for case study 2.

\begin{tabular}{|c|c|c|c|c|c|c|c|}
\hline \multirow{2}{*}{$\mathbf{G}_{\mathbf{j}}$} & \multirow{2}{*}{ Flow $\left(\mathrm{m}^{3} / \mathrm{h}\right)$} & \multirow{2}{*}{$\begin{array}{c}\text { Phenol (mg/l) } \\
\text { Max }\end{array}$} & \multicolumn{2}{|c|}{$\mathbf{p H}$} & \multirow{2}{*}{$\begin{array}{c}\mathrm{NaCl}\left(\mathrm{kg} / \mathrm{m}^{3}\right) \\
\mathrm{Max}\end{array}$} & \multicolumn{2}{|c|}{ Temperature (K) } \\
\hline & & & Min & $\operatorname{Max}$ & & Min & $\operatorname{Max}$ \\
\hline Desalter & 27.50 & 4.5 & 6.7 & 7.5 & 2.0 & 293.00 & 305.00 \\
\hline Sweetening & 45.00 & 5 & 6.3 & 7.8 & 1.0 & 288.00 & 307.00 \\
\hline Quenching & 50.00 & 7 & 7 & 8 & 3.0 & 290.00 & 298.00 \\
\hline Waste & - & 1 & 6 & 8 & 2.0 & 293.00 & 303.00 \\
\hline
\end{tabular}

Table S7. Segregated flowrates from sources, fresh water, treatment unit and RO to sinks for case study 2.

\begin{tabular}{|c|c|c|c|c|c|c|c|c|c|}
\hline \multirow{2}{*}{$\mathbf{G}_{\mathbf{j}}$} & \multirow{2}{*}{ Fresh source $\left(\mathrm{m}^{3} / \mathrm{h}\right)$} & \multirow{2}{*}{ Treatment unit $\left(\mathrm{m}^{3} / \mathrm{h}\right)$} & \multicolumn{6}{|c|}{ Sources $\left(\mathrm{m}^{3} / \mathrm{h}\right)$} & \multirow{2}{*}{ Total $\left(\mathrm{m}^{3} / \mathbf{h}\right)$} \\
\hline & & & $W_{1}$ & $\boldsymbol{W}_{2}$ & $\boldsymbol{W}_{3}$ & $\boldsymbol{W}_{4}$ & $W_{5}$ & $W_{6}$ & \\
\hline Desalter & 23.54 & 0 & 0 & 0 & 0 & 0 & 0.96 & 3.00 & 27.50 \\
\hline Sweetening & 27.09 & 0 & 0 & 0 & 0 & 16.07 & 1.84 & 0 & 45.00 \\
\hline Quenching & 4.67 & 14.76 & 3.00 & 13.63 & 0 & 13.93 & 0 & 0 & 50.00 \\
\hline Waste & - & 0 & 0 & 0 & 0 & 0 & 0 & 0 & 0 \\
\hline
\end{tabular}


Table S8. Sink properties for case study 2.

\begin{tabular}{lccccc}
\hline \multicolumn{1}{c}{$\mathbf{G}_{\mathbf{j}}$} & Flow $\left(\mathbf{m}^{\mathbf{3}} / \mathbf{h}\right)$ & Phenol $(\mathbf{m g} / \mathbf{l})$ & $\mathbf{p H}$ & NaCl $\left(\mathbf{k g} / \mathbf{m}^{\mathbf{3}}\right)$ & Temperature $(\mathbf{K})$ \\
\hline Desalter & 27.50 & 4.5 & 7.13 & 0.1 & 297.97 \\
\hline Sweetening & 45.00 & 5 & 6.44 & 0.3 & 297.67 \\
\hline Quenching & 50.00 & 7 & 7.61 & 0.8 & 297.20 \\
\hline Waste & 0 & - & - & - \\
\hline
\end{tabular}

Table S9. Flowrates from sources to treatment for case study 2.

\begin{tabular}{|c|c|c|c|c|c|}
\hline $\mathbf{h}_{\mathbf{i}}$ & Flow $\left(\mathrm{m}^{3} / \mathrm{h}\right)$ & Phenol (mg/l) & pH & $\mathrm{NaCl}\left(\mathrm{kg} / \mathrm{m}^{3}\right)$ & Temperature (K) \\
\hline Hydroskimmer & 8.87 & 15 & 7.6 & 0.4 & 298.00 \\
\hline Condensate flare & 6.00 & 50 & 8.2 & 3.2 & 303.00 \\
\hline Hydrocracker flare & 0.20 & 35 & 7.8 & 3.0 & 308.00 \\
\hline Total & 15.07 & 29.20 & 7.79 & 2.0 & 300.12 \\
\hline
\end{tabular}

Table S10. Flowrates in the electrocoagulation treatment system for case study 2.

\begin{tabular}{lccccc}
\hline & $\begin{array}{c}\text { Flowrate } \\
\left(\mathbf{m}^{\mathbf{3}} / \mathbf{h}\right)\end{array}$ & $\begin{array}{c}\text { Phenol } \\
(\mathbf{m g} / \mathbf{l})\end{array}$ & $\mathbf{p H}$ & $\begin{array}{c}\mathbf{N a C l} \\
\left(\mathbf{k g} / \mathbf{m}^{\mathbf{3}}\right)\end{array}$ & Temperature (K) \\
\hline $\begin{array}{l}\mathbf{I n} \\
\mathbf{m}\end{array}$ & 15.06 & 29.20 & 7.22 & 2.0 & 300.12 \\
\hline $\mathbf{m}$ & 14.76 & 0.01 & 8 & 2.0 & 293.00 \\
\hline
\end{tabular}


Table S11. Parameters used in the case studies

\begin{tabular}{lc}
\hline \multicolumn{1}{c}{ Concept } & Value \\
\hline Hours of operation per year, $\mathrm{H}_{\mathrm{Y}}(\mathrm{hr} /$ year $)$ & 8000 \\
\hline Factor used to annualize the inversion, $\mathrm{k}_{\mathrm{F}}\left(\mathrm{year}^{-1}\right)$ & 0.24 \\
\hline Unitary price of aluminum $(\$ / \mathrm{kg})$ & 2 \\
\hline Unitary price of cooling $\left(\$ / 10^{6} \mathrm{~kJ}\right)$ & 7.8 \\
\hline Unitary price of steam $\left(\$ / 10^{3} \mathrm{~kJ}\right)$ & 2.48 \\
\hline Unitary price of fresh water $\left(\$ / \mathrm{m}^{3}\right)$ & 0.0676 \\
\hline Unitary price of electricity $(\$ / \mathrm{kWh})$ & 0.2 \\
\hline Unitary price of $\mathrm{NaCl}(\$ / \mathrm{kg})$ & 8.086 \\
\hline Unitary price of reverse osmosis $\left(\$ / \mathrm{m}^{3}\right)$ & 6750 \\
\hline Global heat transfer coefficient, $\mathrm{U}\left(\mathrm{kJ} /\left(\mathrm{h} \mathrm{m}{ }^{2} \mathrm{~K}\right)\right)$ & 8100 \\
\hline Global heat transfer coefficient, $\mathrm{U} 2\left(\mathrm{~kJ} /\left(\mathrm{h} \mathrm{m}{ }^{2} \mathrm{~K}\right)\right)$ & \\
\hline
\end{tabular}

